\title{
Inositol monophosphate phosphatase genes of Mycobacterium tuberculosis
}

Farahnaz Movahedzadeh ${ }^{1,6^{*}}$, Paul R Wheeler ${ }^{2}$, Premkumar Dinadayala ${ }^{3}$, Yossef Av-Gay ${ }^{4}$, Tanya Parish ${ }^{5}$, Mamadou Daffé ${ }^{3}$, Neil G Stoker ${ }^{1}$

\begin{abstract}
Background: Mycobacteria use inositol in phosphatidylinositol, for anchoring lipoarabinomannan (LAM), lipomannan (LM) and phosphatidylinosotol mannosides (PIMs) in the cell envelope, and for the production of mycothiol, which maintains the redox balance of the cell. Inositol is synthesized by conversion of glucose-6phosphate to inositol-1-phosphate, followed by dephosphorylation by inositol monophosphate phosphatases (IMPases) to form myo-inositol. To gain insight into how Mycobacterium tuberculosis synthesises inositol we carried out genetic analysis of the four IMPase homologues that are present in the Mycobacterium tuberculosis genome.

Results: Mutants lacking either impA (Rv1604) or suhB (Rv2701c) were isolated in the absence of exogenous inositol, and no differences in levels of PIMs, LM, LAM or mycothiol were observed. Mutagenesis of cysQ (Rv2131c) was initially unsuccessful, but was possible when a porin-like gene of Mycobacterium smegmatis was expressed, and also by gene switching in the merodiploid strain. In contrast, we could only obtain mutations in impC (Rv3137) when a second functional copy was provided in trans, even when exogenous inositol was provided. Experiments to obtain a mutant in the presence of a second copy of impC containing an active-site mutation, in the presence of porin-like gene of M. smegmatis, or in the absence of inositol 1-phosphate synthase activity, were also unsuccessful. We showed that all four genes are expressed, although at different levels, and levels of inositol phosphatase activity did not fall significantly in any of the mutants obtained.

Conclusions: We have shown that neither impA, suhB nor cysQ is solely responsible for inositol synthesis. In contrast, we show that impC is essential for mycobacterial growth under the conditions we used, and suggest it may be required in the early stages of mycothiol synthesis.
\end{abstract}

\section{Background}

Mycobacterium tuberculosis is a major global pathogen. In 2007, approximately 1.7 million deaths were caused by tuberculosis (TB) and an estimated 9.3 million people acquired the infection [1]. Patients can usually be cured through a six month course of a multiple drug regimen [2]. The efficacy of chemotherapy has however been compromised by the appearance of multi- and extensively drug resistant strains [3,4]. The search for potential novel drug targets and the subsequent development of new antibiotics is therefore urgent. Ideal candidates would be mycobacterial-specific and include pathways involved in the biosynthesis of the unusual cell envelope $[5,6]$; the target of some existing antibiotics, including

\footnotetext{
* Correspondence: movahed@uic.edu

'Department of Pathology and Infectious Diseases, Royal Veterinary College, Royal College Street, London NW1 OTU, UK
}

isoniazid, ethionamide, ethambutol and pyrazinamide [7].

Inositol is a polyol that is not synthesized in most bacterial species. However, in the mycobacteria, inositol is found in lipoarabinomannan (LAM), a lipoglycan that is present in high levels in the cell envelope. LAM is composed of a mannan backbone with branched arabinosyl chains. It is anchored in the cell envelope by means of a phosphatidylinositol (PI) moiety. Other lipoglycans found in the cell envelope include lipomannan (LM) and PI mannosides (PIMs). PI-containing molecules have been demonstrated as essential for growth in the fast-growing species Mycobacterium smegmatis, as mutants lacking PI synthase are not viable [8].

The function of LAM in cell envelope integrity is unknown, but evidence suggests that it has profound effects on the host., for example, it stimulates

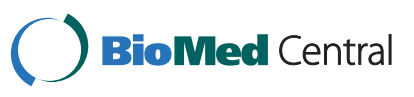


macrophages to produce TNF $\alpha$ [9], nitric oxide [10], and matrix metalloproteinases [11]. LAM may therefore play a major role in the stimulation of an inappropriate host immune response, leading to the pathology that is characteristic of TB. LAM also induces transcriptional activation of HIV-1 $[12,13]$ and may play a role in the synergy seen between HIV and TB. In addition to these effects, LAM is a major antigen $[14,15]$. While some PIMs are probable precursors of LAM, they may also have important functions of their own. PI dimannoside $\left(\mathrm{PIM}_{2}\right)$, for example, has been implicated as a receptor for interacting with mammalian cells [16], as a secreted activator of Toll-like receptor 2 in macrophages leading to TNF $\alpha$ induction [17], and as an inducer of granuloma formation [18].

Inositol is also a constituent of the major mycobacterial thiol, mycothiol (1-D-myo-inosityl-2- [ $N$-acetyl-Lcysteinyl] amido-2-deoxy- $\alpha$-D-glucopyranoside) $[19,20]$, which helps maintain the redox state of the cell and detoxifies harmful molecules. A mutant of M. smegmatis that essentially fails to produce mycothiol is viable, but grows poorly, and is sensitive to $\mathrm{H}_{2} \mathrm{O}_{2}$ [20] However, in $M$. tuberculosis the $m s h A$ and $m s h C$ genes, required for mycothiol biosynthesis, are essential genes [21,22]. Mycothiol may be more important in pathogenic mycobacteria as during infection they would be exposed to reactive oxygen intermediates within the macrophage.

The biosynthesis of inositol normally occurs in two steps. In the first, glucose-6-phospate is converted to inositol-1-phosphate (I-1-P) by inositol phosphate synthase (Ino1). We have shown previously that an ino1 (Rv0046c) mutant of M. tuberculosis is an inositol auxotroph, and is severely attenuated in vivo [23]. In the second step, the I-1-P is dephosphorylated by an inositol monophosphate phosphatase (IMPase) to form inositol. Previously, we identified the M. smegmatis impA gene, which is predicted to encode an IMPase, and showed that inactivation of this gene resulted in an altered colony morphology, reduced levels of PI dimannoside $\left(\mathrm{PIM}_{2}\right)$, and altered permeability of the cell wall. This data suggests that $i m p A$ is partly responsible for inositol synthesis in this species, presumably compensated by the presence of other imp genes [24]. In this paper, we describe the genetic analysis of four IMPase homologues of M. tuberculosis. We demonstrate that three, impA, $\operatorname{suh} B$ and cys $Q$ are dispensible, while impC is essential, even in the presence of exogenous inositol.

\section{Methods}

\section{Bacterial strains, plasmids and media}

Bacterial strains and plasmids used are shown in Table 1. M. tuberculosis H37Rv (ATCC 25618) was cultured on Middlebrook 7H10 agar plus $10 \%$ (vol/vol) oleic acid-albumin-dextrose-catalse (OADC) supplement
(Becton Dickinson). Middlebrook 7H9 broth (Difco) plus $10 \%$ (vol/vol) OADC supplement and $0.05 \%(\mathrm{wt} /$ vol) Tween 80 was used to grow liquid cultures. Hygromycin $\left(100 \mu \mathrm{g} \mathrm{ml}^{-1}\right)$, kanamycin $\left(20 \mu \mathrm{g} \mathrm{ml}^{-1}\right)$, gentamicin $\left(10 \mu \mathrm{g} \mathrm{ml}^{-1}\right)$ and X-Gal (5-bromo-4-chloro-3indolyl- $\beta-D$-galactopyranoside) at $50 \mu \mathrm{g} \mathrm{ml}^{-1}$, were added where appropriate. For supplementation with inositol, a $14 \%$ stock (w/v) (0.77 M) of myo-inositol (Sigma) was prepared and filter-sterilised. E. coli DH5 $\alpha$ was used for all plasmid constructions.

\section{Bioinformatics}

Homology searches were carried out using BLASTP ver 2.2.13 [25] The four homologs identified all had e-values $<10^{-3}$, and no other protein match approached significance. Prosite database information was obtained at http://www.expasy.ch/prosite/, using Release 20.56 dated November $4^{\text {th }}, 2009$.

\section{Construction of $M$. tuberculosis mutants}

Targeted mutagenesis was carried out using a two-step strategy [26] in order to introduce an unmarked mutation without any potential polar effects.

\section{ImpA}

Primers tbimpA1 (CTCGACGTACAGGTTGAGCTATCC) and tbimpA2 (CTTCACCTGACCGATCGTCAGCTC) were used to amplify the $i m p A$ gene and flanking regions (2,108 bp) from M. tuberculosis H37Rv using PCR. The resulting $2.1 \mathrm{~kb}$ fragment was cloned into the EcoRV site of pGEM5, producing pIMP50. A $200 \mathrm{bp}$ SphI fragment within impA was removed following partial digestion and religated to make pIMP51. The 2,348 bp PvuII fragment of pIMP51 was cloned into p2NIL, producing pIMP57.

To create a deletion where the majority of impA was deleted (769 bp deleted from $813 \mathrm{bp}$ ), inverse PCR was performed on pIMP57. Primers tbimpAinv1 (TCGTGCCAGCTGACCAACGAATCCAAGTGCAT) and tbimpAinv2 (TCGTGCCAGCTGATAGGGGAACCAGAGGACTA) were used, simultaneously creating a deletion and introducing a PvuII site in the deleted construct. Following the PCR reaction the DNA was digested with $D p n \mathrm{I}$ for $1 \mathrm{~h}$ at $37 \mathrm{C}$ to destroy the template, then digested with $P v u I I$ and religated to produce pFM74. Insertion of a PacI gene cassette from pGOAL19 was cloned at the $P a c I$ site of pFM74 producing the final delivery plasmid pFM75. The PacI cassette carries lacZ and $s a c B$, which can be used for positive and negative selection of unmarked mutant colonies, respectively.

\section{SuhB}

A 3,534 bp XhoI fragment of cosmid Y5ab was cloned into the SalI site of plasmid p2NIL to produce pFM33. 
Table 1 M. tuberculosis strains and plasmids

\begin{tabular}{|c|c|c|}
\hline Strains/plasmids & Characteristics & Source \\
\hline E. coli DH5 $\alpha$ & & Invitrogen \\
\hline M. tuberculosis H37Rv & wild-type laboratory strain & ATCC 25618 \\
\hline FAME1 & M. tuberculosis suhBA & This study \\
\hline FAME2 & M. tuberculosis impA $\triangle$ & This study \\
\hline FAME4 & M. tuberculosis impCa:pFM96 & This study \\
\hline FAME7 & M. tuberculosis::pFM54 (impC $\triangle \mathrm{SCO}$ ) & This study \\
\hline FAME9 & FAME7 ::pFM96 & This study \\
\hline FAME11 & FAME7::pFM123 & This study \\
\hline FAME63 & FAME7::FM203 & This study \\
\hline FAME5 & M. tuberculosis inols & [23] \\
\hline FAME12 & M. tuberculosis inola:pFM54 (SCO) & This study \\
\hline FAME35 & M. tuberculosis.:.pFM151 (cysQ $\triangle$ SCO) & This study \\
\hline FAME43 & FAME35::FM164 & This study \\
\hline FAME53 & cysQA:FM164 & This study \\
\hline FAME87 & FAME35::FM203 & This study \\
\hline FAME93 & cysQ4:FM203 & This study \\
\hline FAME 120 & $\begin{array}{l}\text { M. tuberculosis } \\
\text { cysQL: pUC-Hyg-int }\end{array}$ & This study \\
\hline pBluescript II SK+ & & Stratagene \\
\hline pGEM5 & & Promega \\
\hline pUC-Gm-int & pUC-based plasmid with Hindlll cassette carrying gm and L5 int & [54] \\
\hline pUC-Hyg-int & pUC-based plasmid with Hindlll cassette carrying hyg and L5 int & [54] \\
\hline $\mathrm{p} 2 \mathrm{NIL}$ & gene manipulation vector, kan & [26] \\
\hline pGOAL19 & hyg AAg $_{85}-1 a c Z$ sacB Pacl cassette vector & [26] \\
\hline pIMP50 & pGEM5::impA & This study \\
\hline pIMP51 & pGEM5::impA $($ Sphl 200 bp) & This study \\
\hline pIMP57 & p2NIL::impA $\triangle$ (Sphl 200 bp) & This study \\
\hline pFM74 & p2NIL::impA $(769$ bp) & This study \\
\hline pFM75 & pFM74 with Pacl cassette of pGOAL19 & This study \\
\hline pFM33 & p2NIL::suhB & This study \\
\hline pFM48 & pFM33::suhBA & This study \\
\hline pFM52 & pFM48 with Pacl cassette of pGOAL19 & This study \\
\hline pFM31 & p2NIL::impC & This study \\
\hline pFM53 & pFM31::impC $\triangle$ & This study \\
\hline pFM54 & pFM53 with Pacl cassette of pGOAL19 & This study \\
\hline pFM94 & pBluescript SK+:.:impC (+288 bp upstream) & This study \\
\hline pFM96 & pFM94::int gm & This study \\
\hline pFM123 & pFM96::impC D86N & This study \\
\hline PMN013 & plasmid carrying the $M$. smegmatis porin gene $m s p A$ & [44] \\
\hline pFM203 & pMN013::int gm & This study \\
\hline pFM145 & p2NIL::CysQ & This study \\
\hline pFM148 & pFM145::.cysQA & This study \\
\hline pFM151 & pFM148 with Pacl cassette of pGOAL19 & This study \\
\hline pFM160 & pBluescript SK+::cysQ (+352 bp upstream) & This study \\
\hline pFM164 & pFM160::int gm & This study \\
\hline
\end{tabular}


A fragment of 817 bp was deleted from the $874 \operatorname{suhB}$ gene by inverse PCR on pFM33 using primers tbsuhB $\Delta 1$ (TCAGCATGCGTTCGTTGTCAGGTCGTGTC) \& tbsuhB $\triangle 2$ (TCAGCATGCGATTCAACGGCCTA GAGC); this introduced a SphI site in the deleted construct. Following treatment with $D p n I$ and SphI, this was religated to produce pFM48. Insertion of the gene delivery cassette from pGOAL19 produced the final delivery plasmid pFM52.

\section{ImpC}

A 2,503 bp StuI fragment of cosmid Y3A2 was cloned into the PmlI site of p2NIL, producing pFM31. A 731 bp deletion was generated in the 783 bp gene by inverse PCR on pFM31 using primers tbimpC $\Delta 1$ (TGCCAGCTGCATTAGATCGTCGTGGCTCA) \& tbimpC $\triangle 2$ (TGCCAGCTGGAGGTGCTGACACGG CTC) to introduce a $P v u I I$ site in the deleted construct. Following treatment with $D p n \mathrm{I}$ and $P v u \mathrm{II}$, this was religated to produce pFM53. Insertion of the delivery gene cassette from pGOAL19 produced the final delivery plasmid pFM54.

\section{CysQ}

Primers tbcysQ1 (CCTGGTCGACCTGTTTCC) and tbcysQ2 (GCGGCTCTTTGACATCTTGT) were used to amplify the $c y s Q$ gene and flanking regions $(2,748 \mathrm{bp})$ from $M$. tuberculosis H37Rv DNA. The product was cloned into the PmlI site of p2NIL, producing pFM145. Primers tbcysQ $\Delta 1$ (AGTCAGGTCGTCCGTCAGATC) \& tbcysQ $\triangle 2$ (TACAACCAACTGGACCCCTAC) were used to generate a $666 \mathrm{bp}$ deletion in the 804 cys $Q$ gene by inverse PCR on pFM145. Following treatment with Klenow polymerase and T4 polynucleotide kinase (Promega), this product was religated to produce pFM148. Insertion of the gene delivery cassette from pGOAL19 produced the final delivery plasmid pFM151.

\section{Mutagenesis}

Deletion plasmids were constructed as described above. The delivery plasmids were introduced into $M$. tuberculosis H37Rv or M. tuberculosis H37Rv ino1, and single crossovers (SCOs) isolated by selection for blue hyg ${ }^{R}$ $\operatorname{kan}^{\mathrm{R}}$ colonies. One SCO colony was plated onto $2 \%$ (wt/vol) sucrose-50 $\mu \mathrm{g} \mathrm{ml}^{-1} \mathrm{X}-\mathrm{Gal}$ to isolate bacteria with a second crossover; this will lead to mutant or wild-type cells depending on the location of the recombination event. In order to screen for impC mutant, DNA was extracted from sucrose ${ }^{\mathrm{S}} \mathrm{kan}^{\mathrm{S}}$ white colonies (obtained from plating M. tuberculosis FAME9 onto sucrose medium) and analysed by PCR using primers that flank the $i m p C$ gene (TBC1: GGACCGCGATCAG TATGAGT and TBC2: TCGACACAGAATCCGC TAGA). Strains carrying the $i m p C$ wild-type allele would produce a band of 1148 bp whereas strains carrying an impC mutation would carry the deletion band of $417 \mathrm{bp}$. Mutant candidates and a wild-type control were digested with $P v u I I$ and subjected to Southern blot analysis using a $2.5 \mathrm{~kb} i m p C$ probe $(i m p C$ plus flanking region). The wild-type strain showed a $4 \mathrm{~kb}$ band whilst the mutant showed a $3.2 \mathrm{~kb}$ deletion band along with a $2.5 \mathrm{~kb}$ band for the integrated impC copy

\section{Complementation}

A construct expressing the $i m p C$ gene was made by PCR amplification of the $i m p C$ gene, together with 288 bp of upstream sequence using chromosomal $M$. tuberculosis $\mathrm{H} 37 \mathrm{Rv}$ as template DNA. The primers tbimpCBamP (CGCGGATCCGGCGATGGTGACAT) and tbimpCBam (CGCGGATCCTTACCCGGCGTTGAGC) were used. The product was digested with $B a m H I$ and cloned into the BamHI site of pBluescript-SK+ to produce pFM94. The HindIII cassette of pUC-Gm-int, carrying the int and $g m$ genes was cloned into the HindIII site of pFM94 to produce pFM96.

A construct expressing the cys $Q$ gene was made by PCR amplification of the cys $Q$ gene including $352 \mathrm{bp}$ of upstream sequence using $M$. tuberculosis H37Rv; chromosomal template DNA; primers tbcysup (GCATA GAGCAGGAGGTTTGC) and tbcysend (GCGCCAC GCGTCGGCGAT) were used. The PCR product was treated with $\mathrm{T} 4$ polynucleotide kinase and cloned into the SmaI site of pBluescript-SK+ to produce pFM160. The HindIII cassette of pUC-Gm-int, carrying the int and $g m$ genes was cloned into the HindIII site of pFM160 to produce pFM164.

\section{Site-directed mutagenesis}

Site-directed mutagenesis was carried out using the non-PCR-based Quickchange kit (Stratagene). Oligonucleotides D86N-forward (GGATCGTAGACCCGAT CAACGGCACCAAAAACTTTGTGC) \& D86N-reverse (GCACAAAGTTTTTGGTGCCGTTGATCGGGTCT ACGATCC) were used to prime DNA synthesis with pFM96. Sequencing confirmed the presence of the required mutation.

\section{Real-time quantitative PCR}

RNA was prepared from an exponential (7-day) rolling culture of M. tuberculosis H37Rv [27] and cDNA synthesis was carried out using Superscript II (Invitrogen) according to the manufacturer's protocol. Primers were designed for Real-time quantitative PCR (RTq-PCR) for $\operatorname{sig} A$ (endogenous control), impA $\operatorname{suh} B, \operatorname{imp} C$ and $\operatorname{cys} Q$ ) using the Primer3 software, ensuring products would be less than $500 \mathrm{bp}$ (Table 2). RTq-PCR reactions were set up using the DyNAmo SYBR Green qPCR kit (MJ Research). RT-qPCR was performed using the DNA 
Table 2 Primers used in Real time quantitative PCR

\begin{tabular}{lll}
\hline Gene & Primer pair & Primer sequence \\
\hline sigA & SIGAF & ATCTGCTGGAAGCCAACCT \\
& SIGAR & GATCACCTCGACCATGTGC \\
\hline impA & IMPAF: & CGATCTCGTCTTCGTCGC \\
& IMPAR: & CCCTATGCTGCCAAGAATCTC \\
\hline suhB & IMPBF: & GCGAGAAGCAGGCAGAATT \\
& IMPBR: & CTCTCGGCGTTGACAACAA \\
\hline impC & IMPCF: & GCTGCTTGAAGATGGCGTC \\
& IMPCR: & CCACCAGGCAGTAAGACAGAA \\
\hline cysQ & CYSQF: & ATCTGACGGACGACCTGACT \\
& CYSQR: & CCAACGGGTCAATAATCCAC \\
\hline
\end{tabular}

Engine Opticon 2 System (Genetic Research Instrumentation) using a standard $1 \times$ DNA master SYBR Green I mix, $1 \mu \mathrm{l}$ cDNA product and $0.3 \mathrm{mM}$ of each primer in $20 \mu \mathrm{l}$ on ice. The primer concentrations had first been optimised. Samples were heated to $95^{\circ} \mathrm{C}$ for $10 \mathrm{~min}$ before cycling for 35 cycles of $95^{\circ} \mathrm{C}$ for $30 \mathrm{~s}, 60^{\circ} \mathrm{C}$ (impA, suhB, $\operatorname{imp} C$ and cys $Q$ ) or $62^{\circ} \mathrm{C}(\operatorname{sig} A)$ for $20 \mathrm{~s}$, and $72^{\circ} \mathrm{C}$ for $20 \mathrm{~s}$. Fluorescence was captured at the end of each cycle after heating to $80^{\circ} \mathrm{C}$ to ensure the denaturation of primer dimers. In order to measure relative gene expression levels, standard curves for each primer set were generated by performing PCR with SYBR green detection on serial dilutions of quantified genomic DNA. $C_{T}$ values were converted into the equivalent of copy number by comparison to the standard curve. Control reactions where RNA had not been reverse transcribed were used to confirm that there was no significant contaminating genomic DNA present. In order to control for any differences in reverse transcriptase efficiencies each value was standardized to $\operatorname{sig} A$ to generate unit-less values. SigA is a major housekeeping gene and levels of sigA mRNA remains constant under a wide range of conditions [28]. Two independent RNA samples were assayed in triplicate for each gene.

\section{Cell wall analysis}

\section{Extraction and analysis of PIMs}

Cells $(0.2 \mathrm{~g})$ were delipidated with chloroform/methanol $(1 / 1, \mathrm{v} / \mathrm{v})$ for $48 \mathrm{~h}$ at room temperature with continuous stirring. Lipids were separated from the delipidated cells by centrifugation ( $3000 \mathrm{rpm}, 15 \mathrm{~min}, 2600 \mathrm{xg}$ ) and analysed by TLC on silica gel-coated plates developed with chloroform/methanol/water $(60: 35: 8, \mathrm{v} / \mathrm{v} / \mathrm{v})$. The various PIMs were identified by their mobilities on TLC and their positive reactivity compared to authentic standards; these included a sugar and phospholipid-specific reagent ( $0.2 \%$ anthrone in concentrated $\mathrm{H}_{2} \mathrm{SO}_{4}$ followed by heating) and the Dittmer-Lester reagent that specifically detects phosphorous-containing lipids, respectively [29].

\section{Production and analysis of $L A M$ and $L M$}

Delipidated cells were washed and disrupted using a Cell disrupter (2 kbars, Constant System Ltd; one shot model). The resulting material was extracted with 40 $\mathrm{mL}$ ethanol/water $(1 / 1, \mathrm{v} / \mathrm{v})$ for $8 \mathrm{~h}$ at $65^{\circ} \mathrm{C}$; the bacterial residues were discarded and the supernatant was dried. Six $\mathrm{ml}$ hot phenol/water $(1 / 1, \mathrm{v} / \mathrm{v})$ were added and the mixture was heated for $1 \mathrm{~h}$ at $70^{\circ} \mathrm{C}$ under continuous stirring, followed by a two-phase partition. The phenol phase was discarded and the upper phase extensively washed and dried. The extract was solubilised in water and Triton X114 ( $2 \% \mathrm{wt} / \mathrm{v})$ was added to the cooled suspension. The mixture was stirred for $10 \mathrm{~min}$ and then heated at $50^{\circ} \mathrm{C}$ until two phases formed. The detergent phase was recovered, diluted by adding $1 \mathrm{ml}$ water and washed three times with $\mathrm{CHCl} 3$. The resulting aqueous phase was dried to evaporate the chloroform and resuspended in water $(0.2 \mathrm{ml})$. This portion was analysed by SDS-PAGE with a $5 \%$ stacking gel and a $15 \%$ running gel. Samples were denatured in the presence of $2 \%$ SDS in $50 \mathrm{mM}$ Tris- $\mathrm{HCl}(\mathrm{pH}$ 6.8). After electrophoresis, gels were treated with periodate/ethanol/acetic acid (0.7/40/ $5, \mathrm{w} / \mathrm{v} / \mathrm{v})$, and silver-stained. Authentic samples of mycobacterial LAM and LM from Mycobacterium bovis BCG were used as standard.

\section{Sugar compositional analysis}

The sugar constituents of the various materials were determined after acid hydrolysis with $2 \mathrm{M} \mathrm{CF}_{3} \mathrm{COOH}$ at $110^{\circ} \mathrm{C}$ for $1 \mathrm{~h}$; the mixture of hydrolysed products was dried, treated with trimethylsilyl reagents [30] to derivatise monosaccharides and analysed by gas chromatography (GC) for their sugars.

\section{Gas chromatography and mass spectrometry}

GC was performed using a Hewlett Packard HP4890A equipped with a fused silica capillary column $(25 \mathrm{~m}$ length $\times 0.22 \mathrm{~mm}$ i.d.) containing WCOT OV-1 $(0.3 \mathrm{~mm}$ film thickness, Spiral). A temperature gradient of $100-290^{\circ} \mathrm{C}$ at $5^{\circ} \mathrm{C}$ min-1, followed by a 10 -min isotherm plateau at $290^{\circ} \mathrm{C}$, was used.

\section{Mycothiol assay}

Labelling of cell extracts with monobromobimane $(\mathrm{mBBr})$ to determine thiol content was performed with modifications to previously published protocols [31,32]. Cell pellets from $3 \mathrm{ml}$ culture were resuspended in 0.5 $\mathrm{ml}$ of warm $50 \%$ acetonitrile-water containing $2 \mathrm{mM}$ $\mathrm{mBBr}$ (Cal Biochem), and $20 \mathrm{mM}$ HEPES- $\mathrm{HCl}, \mathrm{pH}$ 8.0. The suspension was incubated for $15 \mathrm{~min}$ in a $60^{\circ} \mathrm{C}$ water bath and then cooled on ice. A final acidic $\mathrm{pH}$ was produced by adding $2-5 \mu \mathrm{l} 5 \mathrm{M} \mathrm{HCl}$ or $5 \mathrm{M}$ trifluoracetic acid.

The control samples were extracted with $0.5 \mathrm{ml}$ of warm $50 \%$ acetonitrile-water containing $5 \mathrm{mM} \mathrm{N}$-ethylmalemide and $20 \mathrm{mM}$ HEPES- $\mathrm{HCl}, \mathrm{pH}$ 8.0. The suspension was incubated for $15 \mathrm{~min}$ in a $60^{\circ} \mathrm{C}$ water bath and 
then cooled on ice. $2 \mathrm{mM} \mathrm{mBBR}$ were added to the solution followed by a second incubation for $15 \mathrm{~min}$ in a $60^{\circ} \mathrm{C}$. The control sample was cooled but not acidified. Cell debris was pelleted in each sample by centrifugation (5 min $14,000 \times \mathrm{g})$.

HPLC analysis of thiols was carried out by injecting 25 $\mu \mathrm{l}$ of $1: 4$ dilution of samples in $10 \mathrm{mM} \mathrm{HCl}$ on to a Beckman Ultrasphere IP $5 \mu(250 \mathrm{~mm} \times 4.6 \mathrm{~mm})$ column using $0.25 \%$ glacial acetic acid pH 3.6 (buffer A) and $95 \%$ methanol (buffer $\mathrm{B}$ ). The gradient was: $0 \mathrm{~min}$, $10 \% \mathrm{~B} ; 15 \mathrm{~min}, 18 \% \mathrm{~B} ; 30 \mathrm{~min}, 27 \% \mathrm{~B} ; 32 \mathrm{~min}, 100 \% \mathrm{~B}$; $34 \mathrm{~min}, 10 \% \mathrm{~B}$; and $60 \mathrm{~min}, 10 \% \mathrm{~B}$ (reinjection). The flow rate was $1 \mathrm{ml} \mathrm{min}^{-1}$, and the fluorescence detection was accomplished on a Varian Fluorichrom model 430020 with a $370 \mathrm{~nm}$ excitation filter and a 418-700 nm emission filter. Data collection and analysis was performed on Dynamax Mac Integrator (Rainin Instruments).

\section{Impase activity}

Bacteria were grown to mid-log phase, and collected by centrifugation. Each pellet was washed once in distilled water followed by resuspension in $2.5 \mathrm{ml} 2 \mathrm{mM}$ dithiothreitol in $50 \mathrm{mM}$ Tris- $\mathrm{Cl}, \mathrm{pH} 8$. The suspended bacteria were disrupted in a FastPrep220A at $4 \mathrm{~m} / \mathrm{sec}$ for 3 cycles of $20 \mathrm{sec}$ in Lysing Matrix B (0.1 mm silica beads), with cooling on ice between cycles. The resulting cell-extracts were then clarified at $4000 \mathrm{~g}$ for $4 \mathrm{~min}$ using a bench centrifuge and filter-sterilised through $0.2 \mu \mathrm{m}$ pore cellulose acetate filters (Sartorius Minisart). Each clarified cell extract was desalted through Pharmacia PD-10 columns according to the manufacturer's instructions; with the exception that $3.2 \mathrm{ml}$ (not $3.5 \mathrm{ml}$ ) protein fraction was collected. For equilibrating, desalting and eluting using PD-10, $50 \mathrm{mM}$ Tris-Cl, pH8 was used.

Phosphatase assays were conducted using $0.4 \mathrm{mM}$ substrates at $37^{\circ} \mathrm{C}$, as described previously [33] although the reaction volume used was $120 \mu \mathrm{l}$ and was stopped with $30 \mu \mathrm{l}$ malachite green reagent. No precipitates were formed so the entire assay was performed in ELISA plate wells. Inorganic phosphate present in each well was calculated by reading the OD against a standard curve. Enzyme activity was then calculated by subtracting the phosphate formed in wells with cell extract and substrate, from phosphate formed in corresponding wells with cell extract but without substrate.

\section{Results}

\section{Bioinformatics analysis}

There are four genes in the $M$. tuberculosis genome that encode proteins with significant homology to IMPases. All four $M$. tuberculosis proteins are equally distant from the human IMPase (PDB structure 1IMA; 22-30\% identity, 37-46\% similarity) [34] and the aligned amino acid sequences are shown in Figure $1 \mathrm{~A}$. The four proteins are only as similar to each other, as to the human protein (27-32\% identity, 36-44\% similarity).

These four genes are generally conserved in other actinomycete genomes, with for example, apparent orthologs in Mycobacterium avium, Mycobacterium smegmatis, and Corynebacterium glutamicum (data not shown). M. leprae, which has many pseudogenes, has no functional $i m p A$. Other genomes do also have a small number of other IMPase genes (thus, M. avium has a fifth paralog that is similar to cysQ). While levels of homology between the different $M$. tuberculosis IMPase paralogs are moderate (22-30\% amino acid identity), similarities between orthologs are much higher (for example, 75-79\% identity between $M$. tuberculosis and M. leprae, and 51-67\% identity between M. tuberculosis and M. smegmatis).

The genomic contexts of these genes are shown in Figure 2. As with $M$. smegmatis [24], the impA gene $(R v 1604)$ lies in the middle of the main his operon between hisA and hisF. The stop codon of hisA overlaps with the putative start codon of $i m p A$, and the stop codon of $i m p A$ overlaps with the putative start codon of hisF. These $i m p A$ genes are $70 \%$ identical.

The $\operatorname{suh} B$ gene $(R v 2701 c)$ was named in the original genome annotation [35], because it is the gene most similar to the Escherichia coli $s u h B$ gene. The E. coli $\operatorname{suh} B$ gene was so-named because deletion of the gene resulted in a cold-sensitive phenotype, and suppression of a thermosensitive rpoH mutation [36]. It has also been shown to suppress $\sec Y$ [37], dnaB [38], and era [39] mutations. However, these phenotypes are not related to the enzymatic properties of the protein, as they are unaffected by a null point mutation in the active site [40] (Figure 1B). Furthermore, inositol production is not believed to occur in E. coli, so the biological context is very different from that in mycobacteria. Recombinant SuhB from M. tuberculosis has been confirmed to have IMPase activity [41]. SuhB is monocistronic in M. tuberculosis (Figure 2).

The third homologous gene is $R v 3137$, which we have called $i m p C$. It appears to be the first gene in a twogene operon; a $457 \mathrm{bp}$ intergenic gap upstream of $\mathrm{impC}$ suggests it has its own promoter., and a second gene, $p f l A$, is predicted to start only 14 bp downstream, so is probably co-transcribed. PflA shows homology to pyruvate formate lyase-activating proteins. Beyond this is a cluster of fad genes (fadE24-fadE23-fadB4), but the gap beyond pflA and fadE24 is $79 \mathrm{bp}$, so is less likely to be part of the same operon.

The fourth homologous gene is cysQ $(R v 2131 c)$, sonamed because it is most similar to the E. coli cys $Q$ gene. E. coli cys $Q$ mutants are cysteine auxotrophs during aerobic growth [42]. Interestingly M. smegmatis contains two paralogs of this gene. 


\section{(A) \\ Mtb_ImpA Mtb SuhB Mtb_ImpC Mto_CysQ \\ Mtb_ImpA Mtb_suhB Mtb_ImpC Mtb_CysQ \\ Mtb_ImpA Mtb SuhB Mtb_ImpC Mtb_CysQ \\ Mtb_ImpA Mtb_SuhB Mtb-ImpC Mtb_Cyse \\ Mtb ImpA Mtb_SuhB Mtb ImpC Mtb_CysQ}

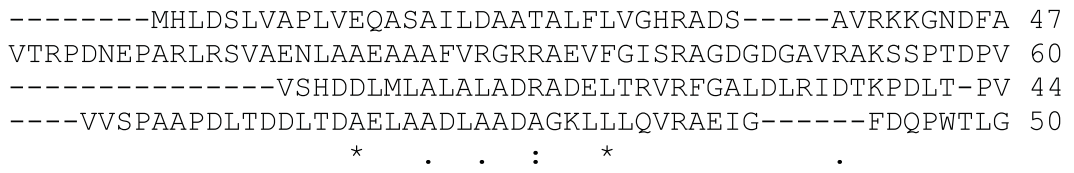

TEVDLAIERQVVAALVAAT-GIEVHGEEFGGPAVDSRW-----VWVLDPIDGTINYAA-G 96 TVVDTDTERLLRDRLAQLRPGDP I LGEEGGGPADVTATPSDRVTWVLDPIDGTVNFVY-G 115 TDADRAVESDVRQTLGRDRPGDGVLGEEFGGSTTFTGR-----QWIVDPIDGTKNFVR-G 94 EAGDRQANSLLLRRLQAERPGDAVLSEEAHDDLARLKSDR---VWIIDPLDGTREFSTPG 103

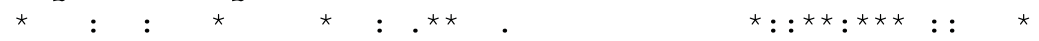

SPLAAILLGLLHDGVPVAGLTWMPFTDPRYTAVAG-GPLIKNGVPQPPLADAELANVLVG 155 IPAYAVSIGAQVGGITVAGAVADVAARTVYSAATGLGAHLTDERGR-HVLRCTGVDELSM 174 VPVWASLIALLEDGVPSVGVVSAPALQRRWWAARGRGAFASVDGARPHRLSVSSVAELHS 154 RDDWAVHIALWRR-----SSNGQPEITDAAVALPARGNVVYRTDTVTSGAAPAGVPGTLR 158

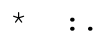

VGTFSADSRGQFPGRYRLAVLEKLSRVSSRLRMHGSTGIDLVFVADGILGGAISFG-GHV 214 ALLGTGFGYSVRCREKQAELLAHVVPLVRDVRRIGSAALDLCMVAAGRLDAYYEHG-VQV 233 ASLSFSS-LSGWARPGLRERFIGLTDTVWRVRAYG-DFLSYCLVAEGAVDIAAEPQ-VSV 211 IAVSATRPPAVLHRIRQTLAIQPVS--------IGSAGAKAMAVIDGYVDAYLHAGGQWE 210

WDHAAGVALVRAAGGVVTDLAGQPWTPASRSALAGPPRVHAQILEILGSIGEPEDY - 270 WDCAAGALIAAEAGARVLLSTPRAG-GAGLVVVAAAPGIADELLAALQRFNGLEPIPD 290 WDLAALDIVVREAGGRLTSLDGVAG-PHGGSAVATNGLLHDEVLTRLNAG-------- 260 WDSAAPAGVMLAAGMHASRLDGS PLRYNQLDPYLPDLLMCRAEVAPILLGAIADAWR- 267 $\star \star \star \star \quad: \quad \star \star \quad: \quad: \quad:$

(B)

\section{Motif 1}

$$
\begin{aligned}
& \text { Mtb_ImpA } \\
& \text { Mtb_SuhB } \\
& \text { Mtb_ImpC } \\
& \text { Mtb_CysQ }
\end{aligned}
$$

\author{
WVLDPIDGTINYA A \\ WVLDPIDGTVNFVY \\ WIVDPIDGTKNFVR \\ WIIDPLDGTREFST

$$
\begin{gathered}
\star:: * \star: * \star \star \quad:: \\
\uparrow \uparrow \uparrow
\end{gathered}
$$

Figure 1 Alignment of IMPases. The M. tuberculosis H37RvIMPases were aligned using ClustalW. (A) Complete sequences. Motifs shown in bold; (B) Prosite motifs: ${ }^{* \prime}$ identical residues in all sequences; '". conserved substitutions; ". semi-conserved substitutions. Sequences were obtained from http://genolist.pasteur.fr/TubercuList/. Reported Prosite motifs are 1 (N-terminal; PS00629): [FWV]-x(0,1)- [LIVM]-D-P- [LIVM]-D- [SG]- [ST]-x(2)- [FY]-X[HKRNSTY]; and 2 (C-terminal; PS00630): [WYV]-D-x- [AC]- [GSA]- [GSAPV]-x- [LIVFACP]- [LIVM]- [LIVAC]-x(3)- [GH]- [GA]. Residues that are not encompassed by these motifs are in bold italics. Arrows indicate putative metal binding aspartate and isoleucine residues reported for human IMPase [55]. The underlined residue shows the aspartate mutated in this study, which is equivalent to mutations introduced into the E. coli and human proteins (see main text). 


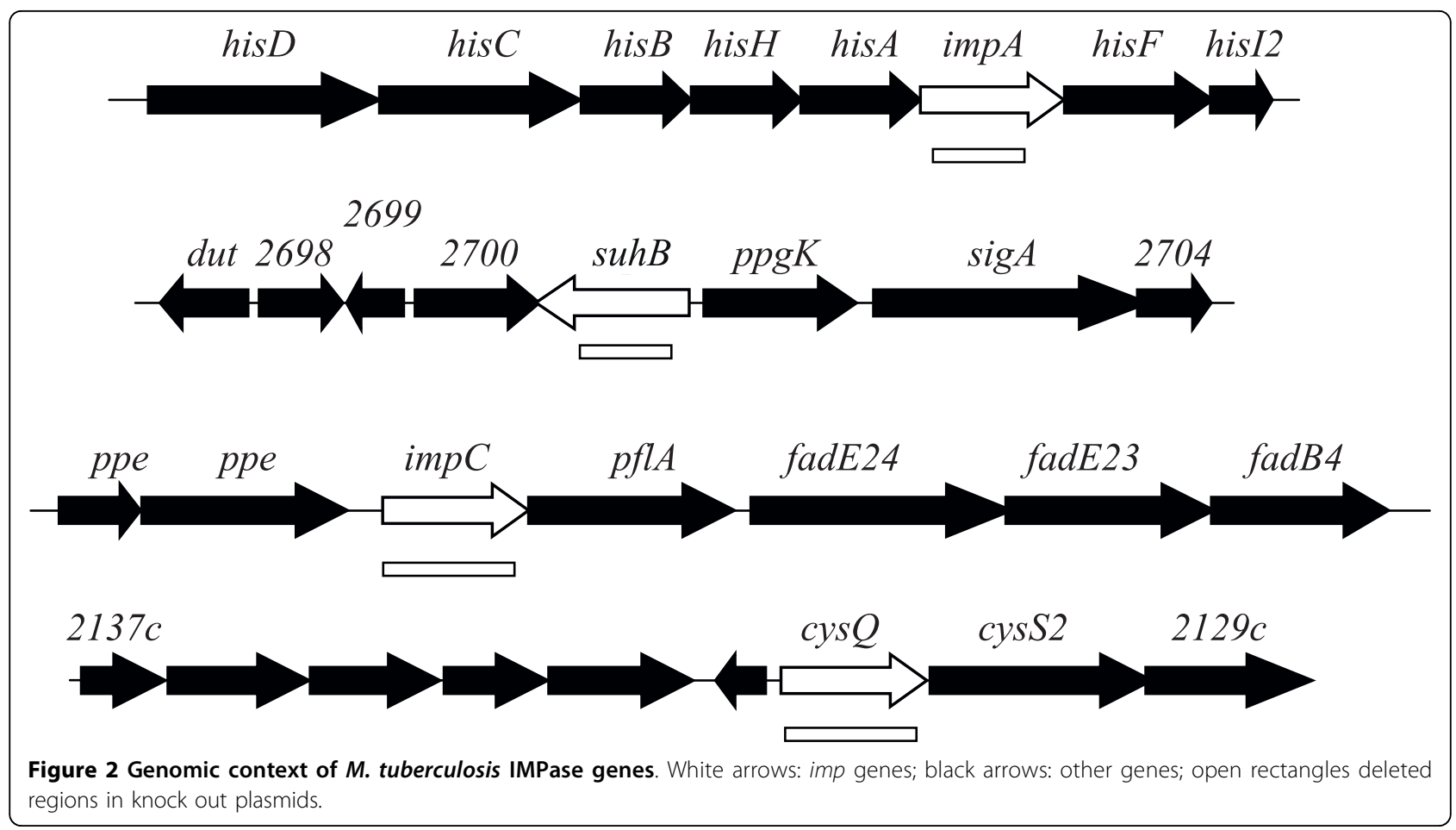

Two sequence motifs have been described for IMPases in the Prosite database [43] (see legend to Figure 1B). One motif, near the N-terminus contains the metalbinding aspartate residues of the active site, and the other lies near the $\mathrm{C}$-terminus. All of the gene products except SuhB had small differences from at least one of the two IMPase motifs (Figure 1B). However, they all contain the important metal-binding residues in both motifs.

The $M$. tuberculosis impA and suhB genes are dispensable The impA gene has previously been shown to play an indirect role in inositol synthesis in M. smegmatis [24], and a knockout plasmid construct was therefore prepared to isolate an $M$. tuberculosis impA mutant. As the gene lies within the his operon (Figure 2), this plasmid carried an unmarked deletion that would not have polar effects. The mutant was generated using a two-step method [26], and grew well on solid medium. Unlike the $M$. smegmatis impA mutant which had altered colony morphology, there were no obvious differences in colony morphology between the wild-type and mutant strains.

We carried out a similar experiment to determine whether $\operatorname{suhB}$ plays a role in inositol metabolism. Again, a deletion construct was prepared, and an unmarked mutant isolated, with no obvious differences in colony morphology.

\section{Inactivation of CysQ}

We constructed a plasmid to delete the cys $Q$ gene. Initially, we were unable to obtain a mutant; of 97 double crossovers (DCOs) screened in the presence of inositol, all were wild-type. We therefore made a merodiploid strain by integrating a second copy of cys $Q$ into the single crossover (SCO) strain, and repeating the selection for DCOs on sucrose. Using this method, 24 out of 30 colonies were found to be mutants. The ability to isolate a mutant only in the presence of a functional copy of the gene indicates that this gene was essential under the conditions tested. It could be inferred that cys $Q$ synthesizes all the inositol in the cell, or all the inositol for a specific essential molecule. However, this hypothesis is improbable, as, if true, we would predict thatmutants would be inositol auxotrophs, yet no mutants were isolated even in the presence of high levels of inositol. One possibility is that inositol does not penetrate the cell wall, which is known to be highly impermeable. However, as we had successfully isolated a mutant lacking inositol-1-phosphate synthase (an inositol auxotroph), only when the media was supplemented with extremely high levels of exogenous inositol (50-77 mM) [23], it seems that inositol does enter the cell in sufficient quantities but permeability to this molecule is poor. This suggests that even a slight increase in the requirement for inositol might make mutant isolation impossible, since we had reached the limits of inositol solubility. 
We reasoned that an increase in the availability of inositol by introduction of a porin might allow a mutant to be isolated. We therefore electroporated an integrating plasmid (pMN013) carrying the M. smegmatis porin gene mspA [44,45] (for which M. tuberculosis has no orthologue) into the SCO strains, and repeated the sucrose selection. Using this method, we successfully isolated a cys $Q$ mutant in the presence of $77 \mathrm{mM}$ inositol. We screened 16 DCO colonies and two were mutants.

We then plated the mutant on inositol-free medium, and were surprised to observe normal growth, indicating that once the mutant has been isolated, it does not require inositol. To determine whether the mutant could survive in the absence of the $m s p A$ gene, the integrating plasmid containing this gene was switched with an empty integrative plasmid carrying the hygromycin resistance gene (pUC-Hyg-int). This would result in the replacement of the cys $Q$-carrying plasmid, leaving a stain with no functional $c y s Q$. Surprisingly, we were able to obtain $c y s Q$ mutants using this approach although we had failed to isolate a mutant by our standard mutagenesis procedure. We therefore conclude that cys $Q$ is also dispensible, and a $c y s Q$ mutant does not require inositol for growth.

\section{The impC gene is essential}

We attempted to construct an unmarked $\operatorname{imp} C$ deletion mutant. The first step of the mutagenesis to produce SCOs worked well, however, when cells carrying a second crossover were isolated, only wild-type bacteria were obtained. In theory, the second crossover could take place on either side of the deletion, resulting in either mutant or wild-type cells. The fact that we obtained only wild-type cells $(n=48)$ suggested that the mutants are not viable.

These initial mutagenesis experiments were carried out in the absence of exogenous inositol. We therefore repeated the mutagenesis, including different levels of inositol in the media at all times. Again, only wild-type bacteria were isolated following the second cross-over $(\mathrm{n}=97 ; 16$ on $15 \mathrm{mM}$ inositol, 8 on $30 \mathrm{mM}, 16$ on 46 $\mathrm{mMl}$, and 57 on $77 \mathrm{mM}$ ).

The inability to obtain a mutant may be due to other factors, such as a low frequency of recombination on one side of the gene, even though the length of flanking DNA should be sufficient (847 and $874 \mathrm{bp}$ ). Therefore we constructed a merodiploid strain by inserting a second functional copy of $i m p C$ into the SCO strain. This extra copy was present on an L5-based integrating vector, and contained $288 \mathrm{bp}$ upstream of $i m p C$, which was likely to carry its promoter. When this strain (FAME9) was plated onto sucrose to isolate DCOs, three out of eight colonies isolated had lost the original copy of $i m p C$. The fact that this gene could only be lost when a second copy of the gene is present suggests that $\operatorname{imp} C$ is essential for survival, even in the presence of high levels of exogenous inositol (Fisher's exact test, $\mathrm{p}<0.01$, comparing only the experiments with $77 \mathrm{mM}$ inositol and the complemented strain). To further investigate the essentiality of the $\operatorname{imp} C$ gene, and in view of what was observed with $c y s Q$, we introduced the $m s p A$ gene into the $\operatorname{impC~SCO~strain;~this~time~we~were~not~successful~}$ in obtaining a mutant, indicating that the difficulty we encountered making an impC mutant differed from cysQ.

A difference between an IMPase mutant and an ino1 mutant may be that inositol-1-phosphate accumulates in the IMPase mutant, which might somehow be detrimental to the cell. We therefore carried out the essentiality experiment in an ino1 mutant background. The impC mutant construct was introduced into $M$. tuberculosis ino1, and a SCO strain isolated. On plating for DCOs, only wild-type colonies were isolated $(\mathrm{n}=38)$, again suggesting that this was not the explanation for the essentiality.

\section{Site directed mutagenesis of impC}

Our results suggest that $i m p C$ does not have a critical role in inositol production and hence our inability to obtain an $i m p C$ mutant may indicate that $i m p C$ has a different or secondary function that prevents isolation of a mutant. For example, the enzyme might form part of an enzyme complex, and play a vital structural role in maintaining the integrity of that complex. Deletion of the gene would then have both enzymatic and structural effects. An analogous situation was found with the $E$. coli SuhB protein; where phenotypes in $\operatorname{suhB}$ mutants were not related to IMPase activity, as a point mutation in the active site did not produce the suppressing phenotype [40]. We therefore used the same approach to try to separate enzymatic activity from a structural role.

A D93N change in E. coli SuhB and an equivalent D90N change in the human IMPase suppress activity $[40,46]$ (Figure 1B). Site-directed mutagenesis was used to introduce a corresponding mutation $(\mathrm{D} 86 \mathrm{~N})$ in the $M$. tuberculosis impC gene using the integrating plasmid pFM96 previously used for complementation. This plasmid (pFM123) was introduced into the SCO strain FAME7, and the resultant strain (FAME11) was streaked onto sucrose/inositol plates. DCO colonies were analysed, and, in contrast to the situation with pFM96, all were shown to be wild-type $(n=52)$. The fact that the functional $\operatorname{imp} C$ gene could not be replaced by this mutated gene, even in the presence of inositol $(\mathrm{p}<$ 0.01 ), shows that the mutation did inactivate enzymatic activity, and (assuming that the structure was not affected) that it is this enzymatic activity that is essential, rather than an additional structural role. 


\section{Enzyme activities}

In order to gain a greater understanding of the function of these IMPases, we expressed $\operatorname{imp} C$ as a recombinant protein. However, despite using different plasmid constructs and strategies, we were unable to obtain a soluble protein (not shown). As an alternative to directly assaying enzyme activity, we assayed IMPase activity in cell extracts of the mutant strains to obtain information about their relative contributions to inositol synthesis. We compared enzyme activities in whole cell extracts from the wild-type and mutant strains (Tables 3 and 4). Of the seven substrates tested, phosphate release as a result of adding the enzyme source was significantly higher than controls for fructose bisphosphate (FBP), the inositol phosphates, 5' AMP and $p$-nitrophenylphosphate. Deletion of the $\operatorname{imp} A, \operatorname{suhB}$, or $c y s Q$ genes made no significant difference to IMPase activity. The cys $Q$ mutants had significantly less FBPase than the parent strain, $(\mathrm{P}<0.05 ; \mathrm{t}$-test $)$. However, the fructose FBPase activity in the $\mathrm{H} 37 \mathrm{Rv}$ control for the cys $Q$ mutants (Table 4) is significantly less than in H37Rv control used for impA and $\operatorname{suhB}$ mutants $(\mathrm{P}<0.05$; $\mathrm{t}$ test) (Table 3 ) suggesting that the small but significant differences reported in this study may be due to batchto-batch variation rather than in relation to any mutations.

\section{PIM, LAM and mycothiol levels are normal in the impA, suhB and cysQ mutants}

Cell extracts of the mutant strains were prepared for the assay of inositol-containing molecules (cell envelope glycolipids and mycothiol). TLC analyses showed that PIMs were normal in the mutant strains (Figure 3A), whilst polyacrylamide gel electrophoresis (Figure 3B) and sugar compositional analysis (not shown) demonstrated normal levels of LAM and LM. Mycothiol levels were assayed by HPLC analysis; levels in the impA, suhB and cys $Q$ mutants were similar to wild-type (see Figure 4).

Table 3 Phosphatases in cell extracts of impA, suhB mutants

\begin{tabular}{llll}
\hline Substrate & H37Rv & $\Delta$ impA & $\Delta$ suhB \\
\hline Fructose-1,6-bisP & $26.04 \pm 1.85(5)$ & $28.18 \pm 0.92(5)$ & $32.70 \pm 0.44(5)$ \\
\hline Inositol-1-P & $0.63 \pm 0.13(6)$ & $0.79 \pm 0.12(5)$ & $0.63 \pm 0.25(6)$ \\
\hline Inositol-2-P & $1.20 \pm 0.15(4)$ & $1.33 \pm 0.22(5)$ & $1.03 \pm 0.15(6)$ \\
\hline Glycerol-2-P & $0.08 \pm 0.06(12)$ & $-0.02 \pm 0.03(2)$ & $0.39 \pm 0.03(2)$ \\
\hline Glycerol-3-P & $-0.13 \pm 0.12(12)$ & $-0.08 \pm 0.03(2)$ & $0 \pm 0.21(2)$ \\
\hline $5^{\prime}$ AMP & $4.22 \pm 0.36(8)$ & $4.13 \pm 0.40(2)$ & $5.74 \pm 0.04(2)$ \\
\hline p-nitrophenyl-P & $3.00 \pm 0.35(12)$ & $3.55 \pm 0.14(2)$ & $4.38 \pm 0.36(2)$
\end{tabular}

Values: $\mathrm{nmol} / \mathrm{min} / \mathrm{mg}$ protein, mean \pm SEM $(\mathrm{n})$. Differences between levels in mutants and the parent strain were not significant $(P>0.05$; t-test).
Table 4 Phosphatases in cell extracts of the cysQ mutants

\begin{tabular}{|c|c|c|c|}
\hline Substrate & H37Rv & $\Delta$ cysQ 203/12 & $\Delta c y s Q 203 / 16$ \\
\hline 5-bisP & $18.94 \pm 1.00(6)$ & $13.09 \pm 1.24(6)$ & $1 \pm 0.54(7)$ \\
\hline ositol-1-P & $.09(8)$ & $0.49 \pm$ & $0.16(9)$ \\
\hline Inositol-2-P & $0.84 \pm 0.12$ (8) & $0.90 \pm 0.27(10)$ & $0.70 \pm 0.23(10)$ \\
\hline Glycerol-2-P & $0.75 \pm 0.32$ & $1.02 \pm 0.27(10)$ & $0.55 \pm 0.15(10)$ \\
\hline Glyce & -0.37 & $4(3)$ & $5(3)$ \\
\hline AMP & $1.42 \pm 0.31$ (3) & $1.69 \pm 0.14(3)$ & $1.39 \pm 0.03$ \\
\hline nitrophenyl-P & $5.51 \pm 0.36(2)$ & $3.64 \pm 1.92(2)$ & $2.83 \pm 0.25$ \\
\hline
\end{tabular}

Values: $\mathrm{nmol} / \mathrm{min} / \mathrm{mg}$ protein, mean $\pm \mathrm{SEM}(\mathrm{n})$. Level of FBPase in cysQ mutants relative to parent strain is significantly different $(P<0.05$; t-test). Level of FBPase in H37Rv parent strain reported in table 4 is significantly different $(P<0.05$; t-test) to that reported in Table 3.

\section{Gene expression levels of imp genes in M. tuberculosis}

The relative contributions of the IMPase homologues will be proportional to their activity, and their level of expression. We therefore carried out RTq-PCR experiments to determine the levels of expression of $i m p A, \operatorname{suhB}, c y s Q$ and impC mRNA in exponential cultures of $M$. tuberculosis. Expression levels were normalized to those of sigA mRNA which remains constant. The level of $c y s Q$ was the highest, almost equal to $\operatorname{sig} A$ (Table 5). impA and $i m p C$ were expressed at approximately $40 \%$ of this level, while $\operatorname{suh} B$ was lowest, at $12 \%$ of the cys $Q$ level.

\section{Discussion}

To investigate how M. tuberculosis synthesises inositol, we carried out a genetic analysis of four IMPase homologues in $M$. tuberculosis. The impA and $s u h B$ genes were shown to be dispensable, with no phenotype detected in terms of the levels of mycothiol, PIMs, LM or LAM. Cys $Q$ is also dispensible, although isolating the mutant proved more difficult, requiring introduction of the $M$. smegmatis $m s p A$ porin gene for mutant isolation, but not for subsequent survival. It cannot be excluded, however, that the cys $Q$ mutants that were eventually obtained had acquired a suppressor mutation, which had allowed deletion of cys $Q$ or had allowed growth of the mutant on media lacking inositol and preventing cell death. In contrast to these three genes, we were only able to inactivate $i m p C$ by introducing a second copy of the gene. The TraSH mutagenesis protocol which provides a genomewide indication of essentiality [47] supports our data, with only impC of these four genes being reported as putatively required for optimal growth in vitro.

Inositol production is likely to be essential for mycobacterial growth, because of the essentiality of both classes of mycobacterial inositol-containing molecules, namely phospholipids [8] and mycothiol Our previous work showing that a PI synthase mutant is an inositol auxotroph [23] is consistent with this. Both SuhB and CysQ have been shown to have IMPase activity $[41,48]$ 


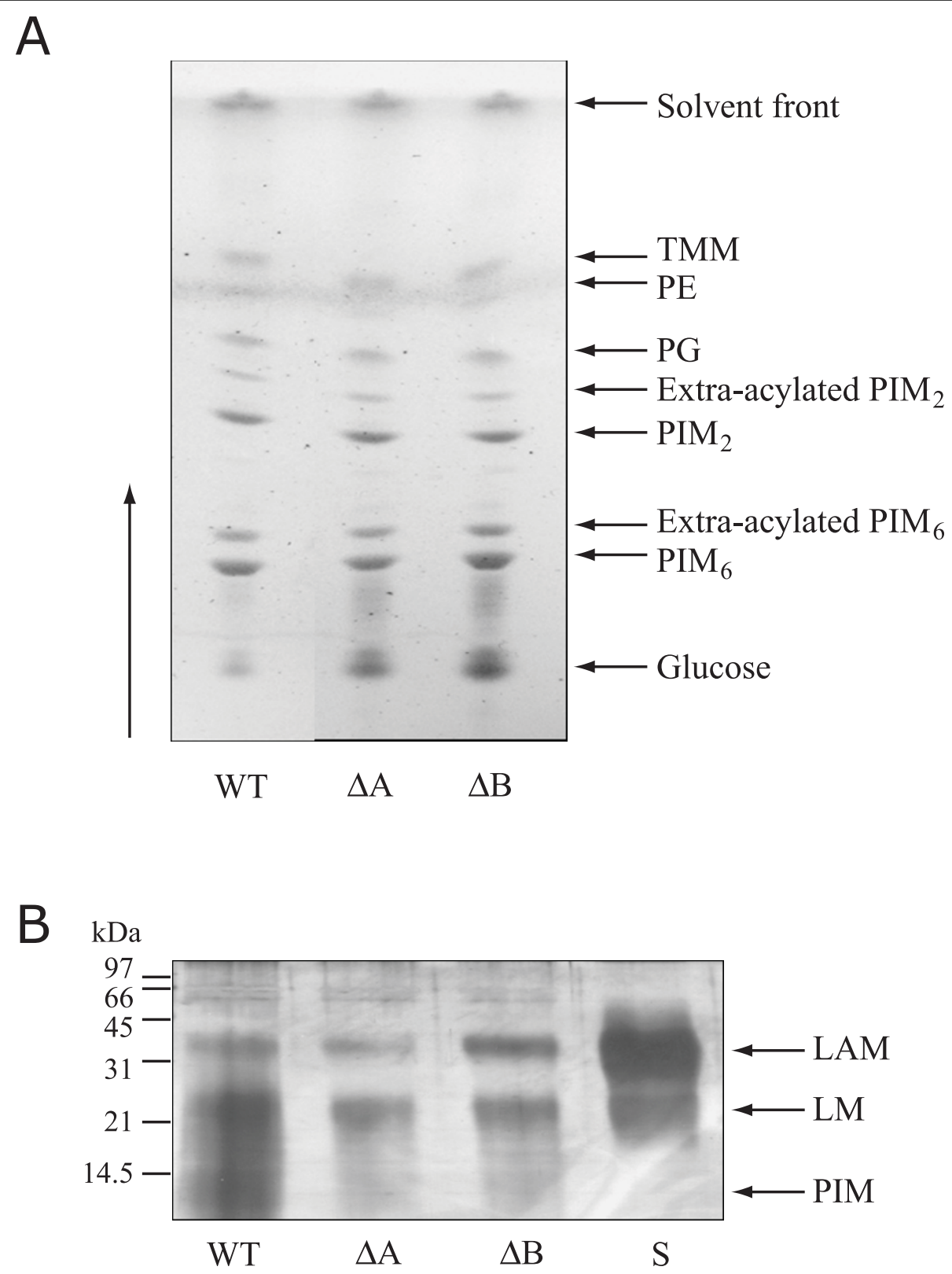

Figure 3 Analyses of cell wall major constituents of some representative mutants; the other strains exhibited profiles similar to those shown. (A) TLC analysis of extractable lipids. (B) SDS-PAGE of lipopolysaccharides. WT: M. tuberculosis H37Rv; $\triangle A$ : impA mutant; $\triangle B$ : suhB mutant; S: authentic standard of mycobacterial LAM and M. bovis BCG LM; TMM: trehalose monomycolate; PE: phosphatidylglycerol; PG:

phosphatidylethanolamine; LAM: lipoarabinomannan; LM: lipomannan; PIM: phosphatidylinositol mannoside.

and we have shown that the M. smegmatis ImpA has IMPase activity (unpublished data). However, none of the three mutants constructed are auxotrophic for inositol, indicating that there is potential redundancy of function between the homologs and deletion of three or four genes might be required to see sufficient loss of activity to cause auxotrophy. A recent report suggests that CysQ is likely to play a role in sulphur metabolism, as its activity as 3'-phosphoadenosine-5'-phosphatase is several orders of magnitude higher than as an inositol phosphatase [49]. However, it may still contribute to the redundancy in inositol phosphatase activity.

To determine the potential relative contribution of each of these genes to inositol synthesis we carried out two experiments. One experiment looked at the relative amounts of mRNA using real-time RTq-PCR. All mRNA species were detectable, with cys $Q$ being most abundant (approximately the same level as sigA, the 


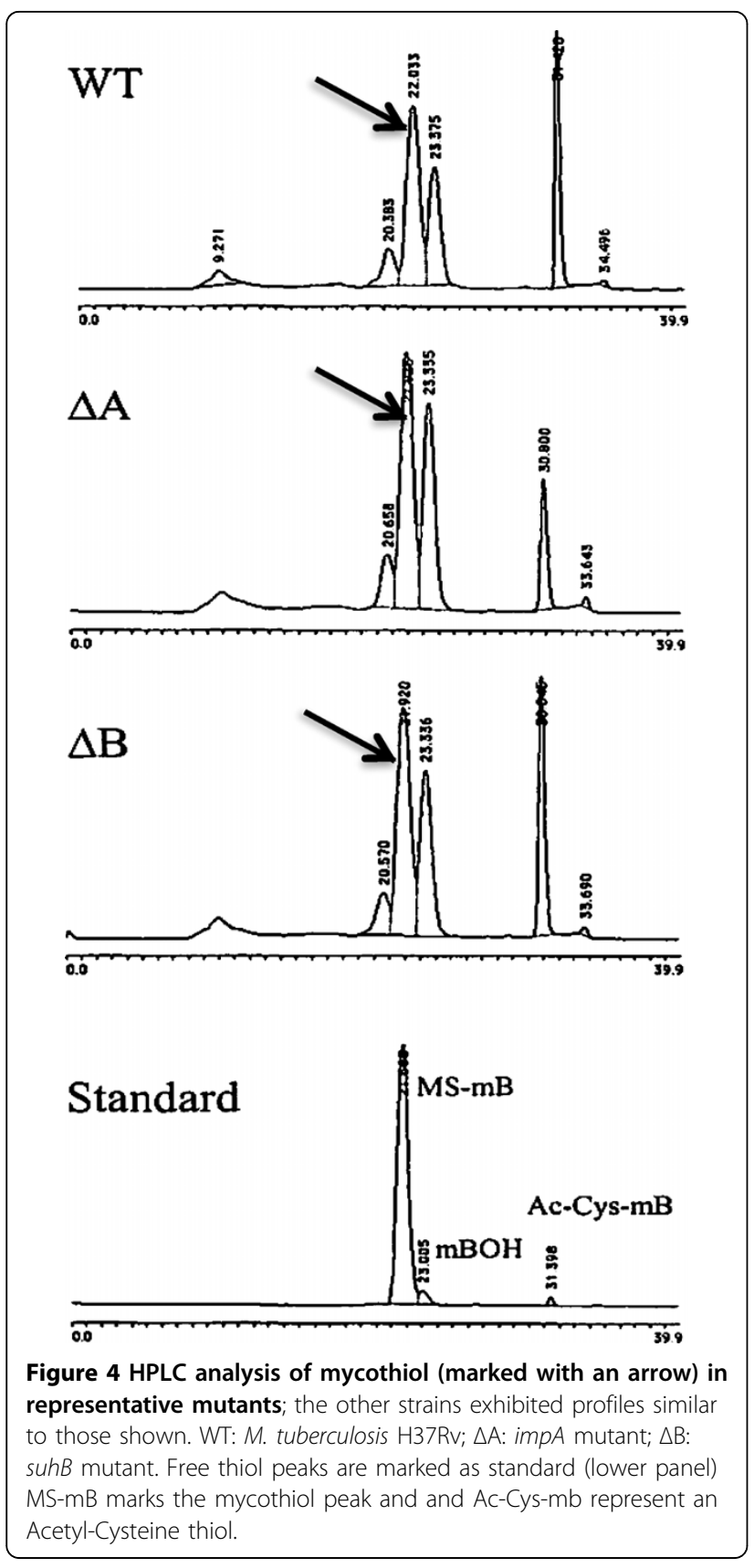

major housekeeping sigma factor), and $\operatorname{imp} A$ being the least abundant, with a level only one-tenth that of $c y s Q$. We also assayed the level of IMPase activity in the whole cell extracts of each mutant, reasoning that we might see a decrease in activity when one of the genes was deleted. However, no decrease in activity was observed in any of the three mutants compared to the wild-type strain. This could be a reflection on the sensitivity of our assay, or could indicate that the activity is regulated (either at the transcriptional or post-transcriptional level) such that a constant level is maintained.
Table 5 mRNA levels

\begin{tabular}{ll}
\hline Gene & mRNA level normalised to sigA* \\
\hline impA & $0.41(0.3-0.5)$ \\
\hline suhB & $0.11(0.096-0.13)$ \\
\hline impC & $0.36(0.27-0.46)$ \\
\hline cysQ & $0.95(0.76-1.18)$ \\
\hline
\end{tabular}

*To ensure equal amounts of cDNA were used each value was standardized to $\operatorname{sig} A$ to generate unit-less values

(95\% confidence interval)

We also have preliminary data that expression of the $i m p C$ gene is regulatable. We grew a $\Delta i n o 1$ mutant of M. tuberculosis (which needs $>50 \mathrm{mM}$ inositol for its normal growth [23]) and looked at the effect of removal of the inositol on gene expression. The only IMPase gene with changed expression was $\operatorname{imp} C$, which was 3fold increased. We cannot link this change directly to the inositol, because it could also be caused by the change in osmolarity, but at the very least indicates this indicates this gene is regulatable (unpublished results).

The situation with $\operatorname{impC}$ is complicated in that we could neither obtain a mutant, nor do we have biochemical evidence that it functions as an IMPase (despite many attempts to achieve both). The essentiality cannot be a simple case of $i m p C$ producing the majority of the inositol in the cell, as we added inositol exogenously. It is true that the ino1 mutant we made previously, which is an inositol auxotroph, required levels of inositol approaching the maximum solubility limit, so a requirement for a slightly increased level of inositol might explain our findings. However, this is unlikely because (i) we also introduced a porin gene to increase inositol uptake, with no effect, (ii) we would also have to explain why the other three IMPase genes are not sufficient, and (iii) the level of $i m p C$ mRNA is only $21 \%$ of the total IMPase mRNA ( $41 \%$ if $c y s Q$ is excluded). The only pieces of evidence we have, therefore, that link impC to inositol production are (i) its clear homology to IMPases, and (ii) the circumstantial evidence that levels of $i m p C$ increased in a microarray experiment where inositol was removed from an ino1 auxotroph, whereas the expression level of the other IMPase genes was not significantly changed. We recognise the difficulty of carrying out the latter experiment in a controlled way since removing such a high level of inositol from the medium could have other effects. Interestingly, $i m p C$ was also upregulated in the Wayne low oxygen model, particularly when $M$. tuberculosis cultures entered a microaerophilic state known as nonreplicating persistent stage 1 (NRP1), where there is cessation of bacterial replication, strong induction of respiratory nitrate reductase activity, and a change in energy metabolism (3.3-fold induced) [50]. 
We tested the hypothesis that the essentiality of $i m p C$ is unrelated to its enzymatic activity by constructing a site-directed mutation. The mutation introduced changes at an active-site of glutamate to glutamine; the analogous mutation has been shown to abrogate activity in the human protein $[40,46]$. Our inability to isolate mutants, strongly suggests that (i) the point mutation does indeed affect the activity of the enzyme and (ii) $\operatorname{imp} C$ carrying this point mutation cannot complement a null mutant even in the presence of inositol. These findings oppose our hypothesis of a structural role for ImpC, and support an enzymatic role, as an explanation of its essentiality. There still remains a possibility that the mutation also affects the structure as we have not shown that folded protein is still produced, but we believe this is unlikely given the subtle nature of the change introduced. Another possible explanation for the inositol-independent essentiality is that removal of ImpC results in a build up of inositol-1-phosphate, which is somehow deleterious to the cell. However, we were unable to obtain an impC mutant in an ino1 background. It is feasible that ImpC uses a substrate other than inositol i.e. one involved in mycothiol production. The elegant work of Fahey and co-workers has defined most of the mycothiol biosynthesis pathway, but is missing a predicted phosphatase., which dephosphorylates $\mathrm{N}$-acetyl glucosamine-( $\alpha 1,3)$-1L-inositol-1-phosphate. We carried out preliminary experiments attempting to make an impC mutant using this substrate (kindly provided by R. Fahey and G. Newton), without success (not shown). However, we have no evidence that it would penetrate the cell, so we feel we cannot draw any conclusions.

The impC gene lies upstream of the $p f l A$ gene and may be co-transcribed, as the intergenic gap is only 19 bp. PflA shows homology to pyruvate formate lyase-activating proteins; oxygen-sensitive iron-sulfur proteins that activate an anaerobic ribonucleotide reductase in some bacteria [51], although there does not appear to be a homologue to E. coli pyruvate formate lyase in the $M$. tuberculosis genome. We designed an unmarked deletion of $i m p C$, in order to prevent polar effects. In addition, complementation with $i m p C$ alone was sufficient to allow mutants to be isolated. We have therefore excluded polar effects on pflA as an explanation for the essentiality.

The Mycobacterium leprae genome contains many pseudogenes therefore genomic comparisons may give an indication as to which mycobacterial genes are essential. In M. leprae, the impA orthologous gene is a pseudogene, with several frameshifts in the distal half of the gene, whereas the other three orthologous IMPase genes are retained. The $\operatorname{suhB}$ orthologous gene (ML1024) appears to be functional, and has a similar genomic context to the $M$. tuberculosis gene. The orthologous impC gene (ML0662) appears to be monocistronic in this species, and the orthologous cys $Q$ gene (ML1301) is also present. The lack of phenotype in an M. tuberculosis impA mutant contrasts with the situation seen in $M$. smegmatis, where an impA mutant had altered colony morphology, slower growth, and reduced levels of $\mathrm{PIM}_{2}$ [24]. The fact that the M. smegmatis mutant is viable supports the idea of some redundancy of function, and we suggest that the differences in phenotype are caused by different levels of ImpA compared to other IMPases in the two species.

Given that inositol monophosphatase and fructosebisphosphatase activities were detected in cell extracts from $\operatorname{imp} A$, suhB and cys $Q$ mutants, none of these genes can encode the major enzyme for these activities. The cys $Q$ gene product does in fact act as a phosphatase with fructose-1,6- bisphosphate and inositol-1-phosphate [48], but enzyme activity in assays does not always equate to functionality in living bacteria. An example is found in Thermococcus kodakarensis where knocking out the $f b p$ gene encoding a fructose bisphosphatase with high substrate specificity resulted in a strain unable to grow on gluconeogenic substrates whilst knocking out its imp gene encoding a member of the carbohydrate phosphate superfamily with substrate specificity including fructose-1,6- bisphosphate did not affect its growth on any carbon sources [52]. In M. tuberculosis, the effect of knocking out the $g l p X$ gene that encodes fructose bisphosphatase is so drastic it is difficult to envisage that $i m p A, \operatorname{suh} B$ or cys $Q$ can compensate for its loss [53].

\section{Conclusions}

We have demonstrated that the $M$. tuberculosis impA, $\operatorname{suh} B$ and $c y s Q$ genes are dispensable, but that $\operatorname{imp} C$ is essential under the growth conditions used. The reason for the essentiality is unclear in terms of inositol synthesis; at present the most attractive hypothesis is that $i m p C$ is required for mycothiol synthesis.

\section{Acknowledgements}

We thank Jane Turner for excellent technical assistance; Bob Cox for the suggestion to use mspA, Gerry Newton, Bob Fahey, Anne Lemassu, Philip Draper and Del Besra for helpful discussions, and Michael Niederweis and Claudia Mailaender for plasmid pMN013. FM was funded by the Wellcome Trust (project grant 051880) and the European Union TB vaccine cluster Contract no. QLK2-1999-01093 and Wellcome Trust grant 073237. PRW was funded by the Department for Environment, Food \& Rural Affairs (UK), and (DEFRA). M. tuberculosis cosmids were kindly provided by Carol Churcher at the Sanger Centre.

\section{Author details}

'Department of Pathology and Infectious Diseases, Royal Veterinary College, Royal College Street, London NW1 OTU, UK. ${ }^{2}$ Tuberculosis Research, Veterinary Laboratories Agency, New Haw, Addlestone, Surrey KT15 3NB, UK. ${ }^{3}$ CNRS, Institut de Pharmacologie et Biologie Structurale, UMR CNRS- 
Université Paul Sabatier (UMR 5089), 205, route de Narbonne, 31077 Toulouse cedex 04, France. ${ }^{4}$ Department of Medicine, Division of Infectious Diseases, University of British Columbia, 2733 Heather St., Vancouver, British Columbia, Canada V5Z 3J5. ${ }^{5}$ Queen Mary University of London, Barts and the London School of Medicine and Dentistry, 4 Newark Street, London E1 2AT, UK. ${ }^{6}$ Current address: Institute for Tuberculosis Research (M/C 964), College of Pharmacy, Rm 412, University of Illinois at Chicago, 833 S. Wood St. Chicago, Illinois USA 60612-7231.

\section{Authors' contributions}

FM carried out the molecular genetic studies, participated in the design and coordination of the study and drafted the manuscript. PW conceived of the study, carried out the enzyme assays and wrote the corresponding section of the manuscript. PD performed cell wall analysis. MD designed the cell wall analysis and aided in drafting the manuscript. YA conceived of the study, designed and carried out the Mycothiol assay. TP conceived of the study, participated in the design and coordination, and aided in drafting the manuscript. NS conceived of the study, participated in its design and coordination, performed the bioinformatics and participated in drafting the manuscript. All authors read and approved the final manuscript.

\section{Received: 8 April 2009}

Accepted: 18 February 2010 Published: 18 February 2010

\section{References}

1. WHO:http://www.who.int/tb/publications/global_report/2009/pdf/full_report. pdf.

2. Dye C, Garnett GP, Sleeman K, Williams BG: Prospects for worldwide tuberculosis control under the WHO DOTS strategy. Directly observed short-course therapy. Lancet 1998, 352(9144):1886-1891.

3. Espinal MA, Laszlo A, Simonsen L, Boulahbal F, Kim SJ, Reniero A, Hoffner S, Rieder HL, Binkin N, Dye C, et al: Global trends in resistance to antituberculosis drugs. World Health Organization-International Union against Tuberculosis and Lung Disease Working Group on AntiTuberculosis Drug Resistance Surveillance. N Engl J Med 2001, 344(17):1294-1303

4. Van Rie A, Enarson D: XDR tuberculosis: an indicator of public-health negligence. Lancet 2006, 368(9547):1554-1556.

5. Daffe $M$, Draper $P$ : The envelope layers of mycobacteria with reference to their pathogenicity. Adv Microb Physiol 1998, 39:131-203.

6. Lee RE, Brennan PJ, Besra GS: Mycobacteriumtuberculosis cell envelope. Curr Top Microbiol Immunol 1996, 215:1-27.

7. Zhang Y, Telenti A: Genetics of drug resistance in Mycobacterium tuberculosis. Molecular genetics of mycobacteria Washington, D.C.: ASM PressHatfull GF, Jacobs WR Jr 2000, 235-254.

8. Jackson M, Crick DC, Brennan PJ: Phosphatidylinositol is an essential phospholipid of mycobacteria. J Biol Chem 2000, 275(39):30092-30099.

9. Moreno C, Taverne J, Mehlert A, Bate CA, Brealey RJ, Meager A, Rook GA, Playfair JH: Lipoarabinomannan from Mycobacterium tuberculosis induces the production of tumour necrosis factor from human and murine macrophages. Clin Exp Immunol 1989, 76(2):240-245.

10. Chan ED, Morris KR, Belisle JT, Hill P, Remigio LK, Brennan PJ, Riches DW Induction of inducible nitric oxide synthase-NO* by lipoarabinomannan of Mycobacterium tuberculosis is mediated by MEK1-ERK, MKK7-JNK, and NF-kappaB signaling pathways. Infect Immun 2001, 69(4):2001-2010.

11. Chang JC, Wysocki A, Tchou-Wong KM, Moskowitz N, Zhang Y, Rom WN: Effect of Mycobacterium tuberculosis and its components on macrophages and the release of matrix metalloproteinases. Thorax 1996, 51(3):306-311.

12. Zhang $Y$, Nakata $K$, Weiden M, Rom WN: Mycobacterium tuberculosis enhances human immunodeficiency virus-1 replication by transcriptional activation at the long terminal repeat. J Clin Invest 1995, 95(5):2324-2331.

13. Bernier R, Barbeau B, Olivier M, Tremblay MJ: Mycobacterium tuberculosis mannose-capped lipoarabinomannan can induce NF-kappaB-dependent activation of human immunodeficiency virus type 1 long terminal repeat in T cells. J Gen Virol 1998, 79(Pt 6):1353-1361.

14. Da Costa CT, Khanolkar-Young S, Elliott AM, Wasunna KM, McAdam KP: Immunoglobulin $\mathrm{G}$ subclass responses to mycobacterial lipoarabinomannan in HIV-infected and non-infected patients with tuberculosis. Clin Exp Immunol 1993, 91(1):25-29.
15. Del Prete R, Picca V, Mosca A, D'Alagni M, Miragliotta G: Detection of antilipoarabinomannan antibodies for the diagnosis of active tuberculosis. Int J Tuberc Lung Dis 1998, 2(2):160-163.

16. Hoppe HC, de Wet BJ, Cywes C, Daffe M, Ehlers MR: Identification of phosphatidylinositol mannoside as a mycobacterial adhesin mediating both direct and opsonic binding to nonphagocytic mammalian cells. Infect Immun 1997, 65(9):3896-3905.

17. Jones BW, Means TK, Heldwein KA, Keen MA, Hill PJ, Belisle JT, Fenton MJ: Different Toll-like receptor agonists induce distinct macrophage responses. J Leukoc Biol 2001, 69(6):1036-1044.

18. Gilleron M, Ronet C, Mempel M, Monsarrat B, Gachelin G, Puzo G: Acylation state of the phosphatidylinositol mannosides from Mycobacterium bovis bacillus Calmette Guerin and ability to induce granuloma and recruit natural killer T cells. J Biol Chem 2001, 276(37):34896-34904.

19. Spies HS, Steenkamp DJ: Thiols of intracellularpathogens. Identification of ovothiol A in Leishmaniadonovani and structural analysis of a novel thiol from Mycobacterium bovis. Eur J Biochem 1994, 224(1):203-213.

20. Newton GL, Bewley CA, Dwyer TJ, Horn R, Aharonowitz Y, Cohen G, Davies J, Faulkner DJ, Fahey RC: The structure of U17 isolated from Streptomyces clavuligerus and its properties as an antioxidant thiol. Eur J Biochem 1995, 230(2):821-825.

21. Buchmeier N, Fahey RC: The mshA gene encoding the glycosyltransferase of mycothiol biosynthesis is essential in Mycobacterium tuberculosis Erdman. FEMS Microbiol Lett 2006, 264(1):74-79.

22. Sareen D, Newton GL, Fahey RC, Buchmeier NA: Mycothiol is essential for growth of Mycobacterium tuberculosis Erdman. J Bacteriol 2003, 185(22):6736-6740

23. Movahedzadeh F, Smith DA, Norman RA, Dinadayala P, Murray-Rust J, Russell DG, Kendall SL, Rison SC, McAlister MS, Bancroft GJ, et al: The Mycobacterium tuberculosis ino1 gene is essential for growth and virulence. Mol Microbiol 2004, 51(4):1003-1014.

24. Parish T, Liu J, Nikaido H, Stoker NG: A Mycobacterium smegmatis mutant with a defective inositol monophosphate phosphatase gene homolog has altered cell envelope permeability. J Bacteriol 1997, 179(24):7827-7833.

25. Altschul SF, Madden TL, Schaffer AA, Zhang J, Zhang Z, Miller W, Lipman DJ: Gapped BLAST and PSI-BLAST: a new generation of protein database search programs. Nucleic Acids Res 1997, 25(17):3389-3402.

26. Parish T, Stoker NG: Use of a flexible cassette method to generate a double unmarked Mycobacterium tuberculosis tlyA plcABC mutant by gene replacement. Microbiology 2000, 146(Pt 8):1969-1975.

27. Betts JC, Lukey PT, Robb LC, McAdam RA, Duncan K: Evaluation of a nutrient starvation model of Mycobacterium tuberculosis persistence by gene and protein expression profiling. Mol Microbiol 2002, 43(3):717-731.

28. Manganelli R, Dubnau E, Tyagi S, Kramer FR, Smith I: Differential expression of 10 sigma factor genes in Mycobacterium tuberculosis. Mol Microbiol 1999, 31(2):715-724.

29. Dittmer JCF, Lester RL: A simple specific spray for the detection of phospholipids on thin layer chromatography. Journal of Lipid Research 1964, 5:126-127.

30. Sweeley CC, Bentley R, Makita M, Wells WW: Gas-liquid chromatography of trimethylsilyl derivatives of sugars and related substances. J Am Chem Soc 1963, 85:2497-2507.

31. Anderberg SJ, Newton GL, Fahey RC: Mycothiol biosynthesis and metabolism. Cellular levels of potential intermediates in the biosynthesis and degradation of mycothiol in mycobacterium smegmatis. J Biol Chem 1998, 273(46):30391-30397.

32. Newton GL, Arnold K, Price MS, Sherrill C, Delcardayre SB, Aharonowitz Y, Cohen G, Davies J, Fahey RC, Davis C: Distribution of thiols in microorganisms: mycothiol is a major thiol in most actinomycetes. $J$ Bacteriol 1996, 178(7):1990-1995.

33. Nigou J, Besra GS: Characterization and regulation of inositol monophosphatase activity in Mycobacterium smegmatis. Biochem J 2002, 361(Pt 2):385-390.

34. Bone R, Frank L, Springer JP, Pollack SJ, Osborne SA, Atack JR, Knowles MR, McAllister G, Ragan Cl, Broughton HB, et al: Structural analysis of inositol monophosphatase complexes with substrates. Biochemistry 1994, 33(32):9460-9467.

35. Cole ST, Brosch R, Parkhill J, Garnier T, Churcher C, Harris D, Gordon SV, Eiglmeier K, Gas S, Barry CE, textitet al: Decipheringthe biology of 
Mycobacterium tuberculosis from the complete genome sequence. Nature 1998, 393(6685):537-544

36. Yano R, Nagai H, Shiba K, Yura T: A mutation that enhances synthesis of sigma 32 and suppresses temperature-sensitive growth of the rpoH15 mutant of Escherichia coli. J Bacteriol 1990, 172(4):2124-2130.

37. Shiba K, Ito K, Yura T: Suppressors of the secY24 mutation: identification and characterization of additional ssy genes in Escherichia coli. J Bacteriol 1986, 166(3):849-856.

38. Chang SF, Ng D, Baird L, Georgopoulos C: Analysis of an Escherichia coli $d n a B$ temperature-sensitive insertion mutation and its cold-sensitive extragenic suppressor. J Biol Chem 1991, 266(6):3654-3660.

39. Inada T, Nakamura Y: Lethal double-stranded RNA processing activity of ribonuclease III in the absence of suhB protein of Escherichia coli. Biochimie 1995, 77(4):294-302.

40. Chen L, Roberts MF: Overexpression, purification, and analysis of complementation behavior of E. coli SuhB protein: comparison with bacterial and archaeal inositol monophosphatases. Biochemistry 2000, 39(14):4145-4153.

41. Nigou J, Dover LG, Besra GS: Purification and biochemical characterization of Mycobacterium tuberculosis SuhB, an inositol monophosphatase involved in inositol biosynthesis. Biochemistry 2002, 41:4392-4398.

42. Neuwald AF, Krishnan BR, Brikun I, Kulakauskas S, Suziedelis K, Tomcsanyi T, Leyh TS, Berg DE: cysQ, a gene neededfor cysteine synthesis in Escherichia coli K-12 only during aerobic growth. J Bacteriol 1992, 174(2):415-425.

43. Hofmann K, Bucher P, Falquet L, Bairoch A: The PROSITE database, its status in 1999. Nucleic Acids Res 1999, 27(1):215-219.

44. Mailaender C, Reiling N, Engelhardt H, Bossmann S, Ehlers S, Niederweis M: The MspA porin promotes growth and increases antibiotic susceptibility of both Mycobacterium bovis BCG and Mycobacterium tuberculosis. Microbiology 2004, 150(Pt 4):853-864.

45. Niederweis M, Ehrt S, Heinz C, Klocker U, Karosi S, Swiderek KM, Riley LW, Benz R: Cloning of the mspA gene encoding a porin from Mycobacterium smegmatis. Mol Microbiol 1999, 33(5):933-945.

46. Pollack SJ, Knowles MR, Atack JR, Broughton HB, Ragan Cl, Osborne S, McAllister G: Probing the role of metal ions in the mechanism of inositol monophosphatase by site-directed mutagenesis. Eur J Biochem 1993, 217(1):281-287.

47. Sassetti CM, Boyd DH, Rubin EJ: Genes required for mycobacterial growth defined by high density mutagenesis. Mol Microbiol 2003, 48(1):77-84.

48. Gu X, Chen M, Shen H, Jiang X, Huang Y, Wang H: Rv2131c gene product: an unconventional enzyme that is both inositol monophosphatase and fructose-1,6-bisphosphatase. Biochem Biophys Res Commun 2006, 339(3):897-904.

49. Hatzios SK, lavarone AT, Bertozzi CR: Rv2131c from Mycobacterium

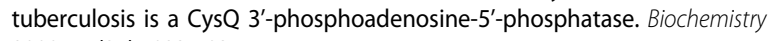
2008, 47(21):5823-5831.

50. Muttucumaru DG, Roberts G, Hinds J, Stabler RA, Parish T: Gene expression profile of Mycobacterium tuberculosis in a non-replicating state. Tuberculosis (Edinb) 2004, 84(3-4):239-246.

51. Tamarit J, Mulliez E, Meier C, Trautwein A, Fontecave M: The anaerobic ribonucleotide reductase from Escherichia coli. The small protein is an activating enzyme containing a [4fe-4s] (2+) center. J Biol Chem 1999, 274(44):31291-31296.

52. Sato T, Imanaka H, Rashid N, Fukui T, Atomi H, Imanaka T: Genetic evidence identifying the true gluconeogenic fructose-1,6-bisphosphatase in Thermococcus kodakaraensis and other hyperthermophiles. $J$ Bacteriol 2004, 186(17):5799-5807.

53. Movahedzadeh F, Rison SC, Wheeler PR, Kendall SL, Larson TJ, Stoker NG: The Mycobacterium tuberculosis Rv1099c gene encodes a GlpX-like class II fructose 1,6-bisphosphatase. Microbiology 2004, 150(Pt 10):3499-3505.

54. Mahenthiralingam E, Marklund Bl, Brooks LA, Smith DA, Bancroft GJ, Stokes RW: Site-directed mutagenesis of the 19-kilodalton lipoprotein antigen reveals No essential role for the protein in the growth and virulence of Mycobacterium intracellulare. Infect Immun 1998, 66(8):3626-3634

55. Gill R, Mohammed F, Badyal R, Coates L, Erskine P, Thompson D, Cooper J, Gore M, Wood S: High-resolution structure of myo-inositol monophosphatase, the putative target of lithium therapy. Acta Cryst 2005, D61:545-555. doi:10.1186/1471-2180-10-50

Cite this article as: Movahedzadeh et al: Inositol monophosphate phosphatase genes of Mycobacterium tuberculosis. BMC Microbiology 2010 10:50.

\section{Submit your next manuscript to BioMed Central and take full advantage of:}

- Convenient online submission

- Thorough peer review

- No space constraints or color figure charges

- Immediate publication on acceptance

- Inclusion in PubMed, CAS, Scopus and Google Scholar

- Research which is freely available for redistribution 